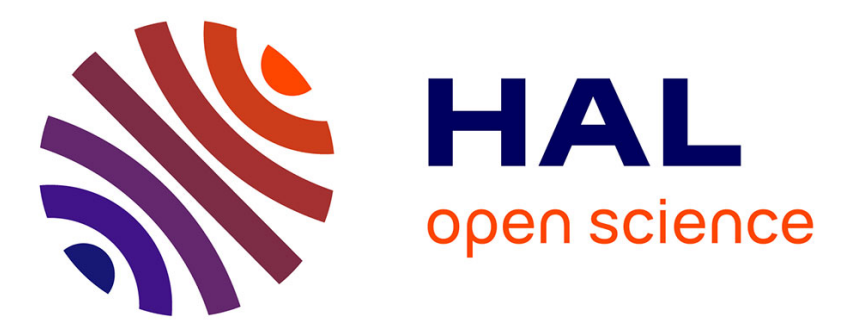

\title{
Book Review: Breaking the Stereotypes: Women in the Arab World
}

\author{
Paola Viviani
}

\section{To cite this version:}

Paola Viviani. Book Review: Breaking the Stereotypes: Women in the Arab World. European Journal of Women's Studies, 2005, 12 (1), pp.124-126. 10.1177/135050680501200114 . hal-00571228

\section{HAL Id: hal-00571228 \\ https://hal.science/hal-00571228}

Submitted on 1 Mar 2011

HAL is a multi-disciplinary open access archive for the deposit and dissemination of scientific research documents, whether they are published or not. The documents may come from teaching and research institutions in France or abroad, or from public or private research centers.
L'archive ouverte pluridisciplinaire HAL, est destinée au dépôt et à la diffusion de documents scientifiques de niveau recherche, publiés ou non, émanant des établissements d'enseignement et de recherche français ou étrangers, des laboratoires publics ou privés. 


\section{BREAKING THE STEREOTYPES: WOMEN IN THE ARAB WORLD}

Manuela Marín and Randi Deguilhem, eds

Writing the Feminine: Women in Arab Sources

London and New York: I.B. Tauris/Strasbourg: The European Science Foundation, 2002, 278 pp., ISBN 1-86064-697-2

Writing the Feminine: Women in Arab Sources is a remarkable work. It is the result of five-years' research carried out by women scholars from the Arab world, Israel and Western Europe, particularly from Spain, who, through this book, greatly contribute to gender investigation in the field of Arab studies as a whole.

Apart from a thorough and in-depth Introduction by the two editors, Manuela Marín and Randi Deguilhem, this book contains 13 chapters, each a highly learned essay, where stress is placed on the lifestyle and the private/public social role of women living in Arab communities up to the 20th century. The essays will undoubtedly prove very useful both to those beginning to study Arab culture and to experienced scholars. As a matter of fact, despite their being accessible to a wide range of readers, whether specialists or not, these pages have a deep scientific rigour. What strikes one most, is how they develop: each author does not broach the chosen subject directly, but touches on others before focusing on a central topic. Thus, they provide the reader with vast information allowing her or him to gain enough background knowledge to fully understand what follows. At the same time, new methodological approaches to source material are suggested.

The sources studied in Writing the Feminine are both written and oral, and vary from literary works (epic, poetry, proverbs and autobiographies) and juridical ones to tafsìr (Koranic exegesis) treatises, as well as hagiographic material and paintings. In other words, they are all documentary sources. The reason why such a choice is of fundamental relevance lies in the fact that this kind of text offers both a deeper and more authentic insight into reality than other types of material, in particular fiction, might do, when considering Arab women's concrete personal/social position in a community strongly influenced by religion, which, however, is not strictly Islam. Aiming to make this point clear, in the Introduction the editors write: 'It is important . . . to underline that in choosing the label, "Arab", for the sources under examination in this volume, the intention is to emphasise the fact that Islam, as a religion, is only one of the factors determining the cultural production of the societies under study' (p. xvi). The Arab people, whether Muslims, Christians or Hebrews, do share a common cultural background; furthermore, one should also keep in mind that women's segregation and culturally imposed passivity - which is widely considered to be almost peculiar to the Islamic society - is something inherent to the Christian one, too.

In this respect, it is particularly interesting to look at 'A Borrowed Space: Andalusi and Maghribi Women in Chronicles' by María Jesús Viguera Molíns. In this essay, before approaching the main topic, the scholar reveals a relevant discovery made over the last two decades - exactly the same period of time in which gender studies in Spain have been initiated - by Spanish Arabists focusing on Andalusi (and Maghribi) women. She explains:

This research [on women in al-Andalus] has shown that the basic and clear difference between men and women consists of performing a leading role as a producer-consumer. With very few exceptions, Andalusi women did not have a role as producer-consumer. The restriction of a woman's role as a producer-consumer in al-Andalus is characteristic of their confinement to the private sphere, not only in Islamic societies, including the Andalusi one, but 
also in the ancient, medieval, modern and contemporary Christian society. Such confinement is conditioned in a general way by the level of economic development. With its cultural and ideological consequences, this development is rooted in the concerned social structure. These conditions more or less restrict the number of roles limited by specific conditions such as gender ... age ... and freedom or the lack of it. ... As in the Andalusi case, this leads to a social structure which can be defined as patriarchal and agnatic whereby a woman depends upon her male relatives. (pp. 165-6)

This passage shows that when dealing with gender problematics in al-Andalus, one should never overlook the fact that Islam and Christianity are equal in the way they have been working through the centuries as potential stumbling-blocks for women's emancipation: thus, the equations Islamic religion = women's total subjection as well as thorough submissiveness, on the one hand, and Christian creed = women's freedom and power, on the other, have to be considered something of a fallacy. This actually means that, within the somewhat strict Islamic rules defining the female sphere of activity from a religious, social, legal and economic perspective, there are important margins of autonomy often depending on marital as well as social status (and by man's sensitivity and understanding).

In the Arab sources studied in Writing the Feminine, it is common, for example, to read about medieval women from the upper social classes, who, despite their high position, could neither move or dress of their own will nor follow their lessons unless from behind a screen, if the teacher was not a close male relative. On the other hand, it is easy to find women in the countryside or those belonging to the lower degrees of the social ladder (slave-girls above all) coming in and out of where they lived without restraint. But, what is really important here is the fact that the scholars have discovered that, in specific situations, some restrictions to women's autonomy were dictated by fear of evil practices seemingly in widespread use rather than by a blind acceptance of and faithful obedience to religious or traditional codes.

Emphasis has also been put on the Andalusi (and/or Maghribi) women's 'capacity to act' and their 'possibilities for divorce' as well as on their very often painful submission to the practice of polygamy and on the difficulties they faced when choosing a holy life (as prophets or saints), a practice opposed because it was considered rebellious (although more to the world in general than to the rules of patriarchal society).

In two of the texts, however, which analyse source material going back to the 10th century, new light is shed on women's position within the particular context of Abbasid Baghdadi society, where they were even allowed to reach full power, and marriage could be a love-based contract rather than a mere economic and legal one. This is the reason why, at the end of the essay 'Women's History: A Study of al-Tanūkhī', Nadia Maria El-Cheikh comments:

Al-Tanūkhī's [an important male prose writer who died in 994] works are important for informing us that a particular sentiment existed, that it was possible for women to be involved in specific productive activities and that a number of them could become quite influential and wealthy.

Most especially, the Baghdad of al-Tanūkhī is peopled with vivid and lively female characters whose lives the reader is made to share in their most intimate detail. (p. 145) 
And it is not only in the medieval oriental Middle East that this sense existed and was expressed, but also in the more traditional West, that is al-Andalus, where the outstanding Islamic 12th-century philosopher Averroes wrote some texts which have been defined as 'almost "feminist" in character or rather "humanistic"' (p. 170).

Whether consciously or not, much of these representations of Arab women have become part of the 19th- and 20th-century Arabs' culture and gender views, although, since the 1950s (and since 1967, for Palestine) much has been put into question again, due to the people's need for a 'return-to-roots' search for something whereby they can overcome extremely serious social, economic and political problems affecting the Arab world as a whole. This is particularly true for Palestine, where painters describe women as the symbol of the suffering Arab land and writers represent a society trying to regain traditional values and lifestyles in order to forget a cruel present.

But one must not think that Arab women's independence is just an illusion, because, despite the huge difficulties they have to face, their reality is very far from the stereotypical images common, say, in some medieval classical poetry and proverbs (which, however, may also turn out to be texts of paramount relevance to the historian, as widely shown in Writing the Feminine). And this development is mainly due to far-sighted men and women who have striven much (and still do) to allow Arab women to gain enduring self-assertion. Among them, gender female investigators.

Paola Viviani

Università degli Studi di Napoli 'L'Orientale' 